\title{
Pengaruh Komunikasi, Motivasi dan Lingkungan Kerja terhadap Kinerja Karyawan Pada PT. Nutrifood Medan
}

\author{
Pita Karni Zendrato ${ }^{1}$ \\ Program Studi Manajemen STMB Multismart \\ Jalan Merbabu Dalam No. 32 aa-bb Kota Medan \\ Pitakarni99@gmail.com

\section{Latersia Br Gurusinga ${ }^{2}$} \\ Program Studi Manajemen STMB Multismart \\ Jalan Merbabu Dalam No. 32 aa-bb Kota Medan \\ latersiagurusinga76@gmail.com
}

\begin{abstract}
Abstrak Employee performance is very dependent on the input generated by the employee and the output unit produced by the employee. The purpose of this study was to determine and analyze communication, motivation and work environment influence on performance partially and simultaneously. The research used is research with quantitative methods. The technique of collecting data in this study was done by distributing questionnaires. The data analysis technique in this study used the classical assumption test, multiple regression, hypothesis testing with SPSS 22 software. The population in this study was 83 employees at PT. Nutrifood Medan. Based on the results of this study, the significance value of communication on performance based on the $t$ test was obtained for tcount > ttable $(3.857>2.001)$. thus the conclusion: communication has a positive and significant effect on performance. Based on the results of this study, the significance value of motivation based on the t-test was obtained at tcount > ttable $(4.912>2.001)$. thus the conclusion: motivation has a positive and significant effect on employee performance. based on the t test, it was obtained that tcount > ttable $(2,661>2,001)$. thus $H 1$ is accepted. the conclusion: the work environment has a positive and significant effect on employee performance at PT. Nutrifood Medan. based on the results of the $F$ test above, the value of Fcount $>$ Ftable is $(25,636>3.16)$ (Sig. $0.000<0.05$ ), thus the conclusion: communication, employee placement and work environment have a positive and significant impact on employee performance
\end{abstract}

Kata Kunci Communication, Motivation, Work Environment, Performance

\section{PENDAHULUAN}

Faktor-faktor yang mempengaruhi kinerja karyawan yaitu kemampuan dan keahlian, pengetahuan, rancangan kerja, kepribadian, kepemimpinan, gaya kepemimpinan, budaya organisasi, kepuasan kerja, loyalitas, komitmen, disiplin kerja, komunikasi kerja, motivasi kerja, dan lingkungan kerja.

Baik atau buruknya komunikasi karyawan dalam bekerja akan berpengaruh terhadap kinerja karyawan. Hal ini sejalan dengan hasil penelitian terdahulu yang dilakukan (Fachrezi \& Khair, 2020:117), (Julita \& Arianty, 2019:204), (Kamal, 2015:69),(Wandi \& Adha, 2019:27), dan (Ardiansyah, 2016:27) yang menyimpulkan bahwa komunikasi berpengaruh signifikan terhadap kinerja karyawan.

Motivasi kerja merupakan cara mengarahkan daya dan potensi bawahan, agar mampu bekerja sama secara produktif, berhasil mencapai suatu dan mewujudkan tujuan yang telah 
ditentukan. Motivasi kerja yang tinggi dari setiap karyawan sangat diperlukan guna peningkatan kinerja perusahaan. Hal ini sejalan dengan hasil penelitian yang dilakukan oleh (Hidayat et al., 2020:203), (Jufrizen \& Pulungan, 2017), (Rivai, 2021), (Astuti \& Suhendri, 2019), (Jufrizen \& Hadi, 2021), (Sembiring, Jufrizen, \& Tanjung, 2021), (Jufrizen, 2017), (Gultom, 2014:183), (Farisi, Irnawati, \& Fahmi, 2020), (Farisi et al., 2020), (Marjaya \& Pasaribu, 2019:140), dan (Prayogi \& Nursidin, 2018)yang menyatakan bahwa motivasi kerja berpengaruh secara signifikan dan positif terhadap kinerja karyawan

Faktor pendorong dalam kinerja karyawan lainnya adalah lingkungan kerja, dimana lingkungan kerja juga merupakan salah satu faktor yang mempengaruhi kinerja karyawan. Oleh karena itu suatu perusahaan diharapkan agar bisa menciptakan lingkungan kerja yang kondusif, karena lingkungan kerja yang nyaman akan mendorong peningkatan kinerja karyawan. Hal tersebut sejalan dengan hasil penelitian yang dilakukan oleh (Elizar \& Tanjung, 2018: 2018:57), (Fachrezi \& Khair, 2020:117), (Farisi \& Fani, 2019), (Jufrizen \& Rahmadhani, 2020:77), dan (Kusumastuti et al., 2019:51) yang hasil penelitiannya menyatakanbahwa lingkungan kerja memiliki pengaruh yang positif dan signifikan terhadap kinerja karyawan.

Berdasarkan uraian di atas maka penulis tertarik untuk meneliti Pengaruh Komunikasi, Motivasi dan Lingkungan Kerja terhadap Kinerja Karyawan Pada PT. Nutrifood Medan. Adapun tujuan dari penelitian ini adalah: Untuk menganalisis pengaruh komunikasi kerja terhadap kinerja karyawan pada PT. Nutrifood Medan. Untuk menganalisis pengaruh motivasi kerja terhadap kinerja karyawan pada PT. Nutrifood Medan. Untuk menganalisis pengaruh lingkungan kerja terhadap kinerja karyawan pada PT. Nutrifood Medan. Untuk menganalisis pengaruh komunikasi kerja, motivasi kerja dan lingkungan kerja secara simultan terhadap kinerja karyawan pada PT. Nutrifood Medan. Hasil penelitian ini diharapkan dapat memberikan kontribusi bagi perkembangan ilmu pengetahuan pada khususnya, maupun bagi perusahaan atau instansi pada umumnya mengenai pengaruh antara komunikasi kerja, motivasi kerja dan lingkungan kerja terhadap kinerja karyawan

\section{LANDASAN TEORI}

\section{KINERJA}

Kinerja Kinerja merupakan perilaku nyata yang ditampilkan setiap orang sebagai prestasi kerja yang dihasilkan oleh pegawai sesuai perannya dalam instansi. Kinerja merupakan suatu hal yang sangat penting dalam upaya instansi untuk mencapai tujuannya. Kasmir, (2016) menjelaskan bahwa kinerja merupakan hasil kerja dan perilaku kerja seseorang dalam suatu periode, biasanya 1 tahun. Kinerja adalah bagaimana sesorang yang diharapkan dapat berfungsi dan berperilaku sesuai dengan tugas yang telah dibebankan kepadanya (Miner dalam Sutrisno, 2016). Menurut Mangkunegara, (2018) kinerja adalah hasil secara kualitas dan kuantitas yang dicapai oleh seseorang karyawan dalam melaksanakan tugasnya sesuai dengan tanggung jawab yang di berikan kepadanya. Siagian, (2014) kinerja dapat diartikan sebagai hasil pekerjaan yang dicapai selama tahun waktu tertentu. Kinerja karyawan merupakan suatu ukuran yang dapat diberikan organisasi pada periode tertentu dan dapat digunakan untuk mengikuti prestasi kerja. Terdapat beberapa faktor-faktor yang mempengaruhi kinerja menurut (Sutrisno, 2016) yaitu efektifitas dan efisiensi, otoritas dan tanggung jawab, disiplin kerja dan inisiatif. Faktor-faktor lain yang mempengaruhi pencapaian kerjamenurut (Mangkunegara, 2018) adalah faktor kemampuan dan faktor motivasi. Untuk mengukur kinerja dapat di gunakan beberapa indikator mengenai kriteria kinerja yakni: kualitas, kuantitas, ketepatan waktu, efektivitas biaya, kebutuhan akan pengawasan, dan hubungan antar perseorangan. Indikator inilah yang akan menjadi patokan dalam mengukur kinerja, (Kasmir, 2016) yaitu kualitas (mutu), kuantitas (jumlah), waktu (jangka waktu), penekanan biaya, pengawasan dan hubungan antar rekan kerja. Sedangkan indikator lain dari kinerja menurut (Mangkunegara, 2018) adalah kualitas kerja, kuantitas kerja, keandalan dan sikap.

KOMUNIKASI

Hamali, (2016) mengatakan bahwa komunikasi kerja adalah suatu proses penyampaian ide-ide dan informasi berupa perintah dan petunjuk kerja dari seorang pimpinan kepada karyawan atau 
para bawahannya untuk melaksanakan tugas - tugas kerja dengan sebaik-baiknya. Mangkunegara, (2018) mengatakan komunikasi ialah proses pemindahan suatu informasi, ide, pengertian dari seseorang kepada orang lain dengan harapan orang lain tersebut dapat menginterprestasikan sesuai dengan tujuan yang dimaksud. Wibowo (2015) mengatakan bahwa komunikasi adalah merupakan proses penyampaian informasi dari satu pihak baik individu, kelompok atau organisasi sebagai sender kepada pihak lain sebagai receiver untuk memahami dan terbuka peluang memberikan respon balik kepada sender. Menurut pendapat diatas, dapat disimpulkan bahwa komunikasi adalah proses penyampaian informasi dari ide -ide dari satu pihak ke pihak lain, baik dari individu maupun kelompok untuk dapat menginterprestasikan yang dimaksud dan melaksanakan tugas - tugas dengan sebaik - baiknya. Ada dua tinjau faktor-faktor yang mempengaruhi komunikasi yaitu : (1) Faktor dari pihak sender atau disebut pula komunikator terdiri dari : a) keterampilan sender, b) sikap sender, c) pengetahuan sender, dan d) media saluran yang digunakan oleh sender. (2) Faktor Dari Pihak Receiver, yaitu : a) keterampilan receiver, b) sikap receiver, c) pengetahuan receiver dan d) media saluran komunikasi (Mangkunegara, 2018). Sedangkan faktor - faktor yang mempengaruhi komunikasi menurut (Handoko, 2016) adalah perkembangan, persepsi, nilai, latar Belakang Sosial Budaya dan emosi. Indikator - indikator komunikasi menurut Muhammad dalam (Usman, 2011) adalah keterbukaan (opennes), Empati (empaty), dukungan (support), rasa positif (positiveness), pengetahuan (knowledge), keterampilan (skills) dan sikap (attitude).

MOTIVASI

Motivasi merupakan dorongan untuk bertindak terhadap serangkaian proses perilaku manusia dengan mempertimbangkan arah, intensitas, dan ketekunan pada pencapaian tujuan. Adapun elemen yang terkandung dalam motivasi meliputi unsur membangkitkan, mengarahkan, menjaga, bersifat terus-menerus dan adanya tujuan (Wibiwo Wibowo, 2014). (Sutrisno, 2016), mengatakan bahwa motivasi memiliki komponen, yakni kompenen dalam dan luar. Komponen dalam ialah perubahan dalam diri seseorang, keadaan merasa tidak puas, ketegangan psikologis. Komponen luar ialah apa yang di inginkan seseorang, tujuan yang menjadi arah tingkah lakunya. Jadi, komponen dalam adalah kebutuhan - kebutuhan yang ingin di puaskan, sedangkan komponen luar adalah tujuan yang hendak dicapai.

\section{LINGKUNGAN KERJA}

Lingkungan kerja merupakan suatu lingkungan dimana para pegawai bekerja dan dapat mempengaruhi mereka dalam menjalankan tugas-tugas yang dibebankan. Sedarmayanti, (2017) menyatakan bahwa Lingkungan kerja adalah keseluruhan alat perkakas dan bahan yang dihadapi, lingkungan sekitarnya di mana seseorang bekerja, metode kerjanya, serta pengaturan kerjanya baik sebagai perseorangan maupun sebagai kelompok. Menurut Nitisemito, (2011) mendefinisikan lingkungan kerja sebagai segala sesuatu yang ada di sekitar para pekerja yang dapat mempengaruhi dirinya dalam menjalankan tugas - tugas yang diembankan. Menurut (Sunyoto, 2012), mengatakan bahwa lingkungan kerja merupakan bagian yang sangat penting di dalam karyawan melakukan aktivitas bekerja. Dengan memperhatikan lingkungan kerja yang baik atau menciptakan kondisi kerja yang mampu memberikan motivasi untuk bekerja, maka akan membawa pengaruh terhadap kegairahan atau semangat karyawan dalam bekerja. Menurut (Hidayat \& Taufiq, 2012), lingkungan kerja sebagai sumber informasi dan tempat melakukan aktifitas, maka kondisi lingkungan kerja yang baik harus dicapai agar karyawan merasa betah dan nyaman didalam ruangan untuk menyelesaikan pekerjaan sehingga dapat efesiensi yang tinggi.

\section{METODOLOGI PENELITIAN}

Penelitian ini menggunakan pendekatan desain kausal. Menurut (Sugiyono, 2018:30) desain kausal adalah penelitian yang bertujuan menganalisis hubungan sebab akibat antara variabel independen (variabel yang mempengaruhi) dan variabel dependen (variabel yang dipengaruhi). Penelitan ini dilakukan di PT. Nutrifood Medan yang beralamat di Jalan Pulau Irian No.88, Kawasan Industri Medan No.1, Sampali. Jenis data yang digunakan dalam penelitian ini adalah data primer. Data primer yang digunakan dalam penelitian ini adalah kuesioner yang akan 
disebar berdasarkan jumlah sampel yang diteliti. Populasi dari penelitian ini adalah seluruh karyawan PT. Nutrifood Medan pada Tahun 2021 yang berjumlah 104 orang. Dalam menentukan jumlah sampel yang akan dipilih, penulis menggunakan tingkat kesalahan sebesar 1\%, karena dalam setiap penelitian tidak mungkin hasilnya sempurna $100 \%$, makin besar tingkat kesalahan maka semakin sedikit ukuran sampel. Jumlah populasi sebagai dasar perhitungan yang digunakan adalah 100 orang, maka jumlah sampel dapat ditentukan dengan perhitungan sebagai berikut:

$$
\begin{aligned}
& \mathrm{n}=\frac{104}{1+104 \times 0,05^{2}} \\
& \mathrm{n}=\frac{104}{1+104 \times 0,0025} \\
& \mathrm{n}=\frac{104}{1+0,26} \\
& \mathrm{n}=\frac{104}{1,26} \\
& \mathrm{n}=82,5=83
\end{aligned}
$$

Berdasarkan rumus tersebut dapat dihitung sampel dari populasi berjumlah 83 orang karyawan PT. Nutrifood Medan pada tahun 2021. Berdasarkan perhitungan dengan menggunakan rumus Slovin di atas dapat disimpulkan bahwa jumlah sampel dalam penelitian ini sebanyak 83 orang yang diambil dari karyawan tetap pada bagian Pengembangan dan SDM, Administrasi dan Keuangan, Operasional, Kekaryawanan, dan Perencanaan di PT. Nutrifood Medan pada tahun 2021. Pengukuran berdasarakan : (1) variabel independen dalam penelitian ini adalah komunikasi (X1), Motivais kerja (X2), Lingkungan kerja (X3) dan (2) variabel independen dalam penelitian menggunakan Kinerja (Y). Teknik analisis yang digunakan dalam penelitian ini adalah analisis data kuantitatif, pengujian tersebut dengan alat uji regresi berganda tetapi dalam praktiknya pengolahan data penelitian ini tidak diolah secara manual, namun menggunakan software statistik SPSS

\begin{tabular}{|c|c|c|c|c|c|c|c|}
\hline \multirow[b]{2}{*}{ Model } & \multicolumn{2}{|c|}{$\begin{array}{c}\text { Unstandardized } \\
\text { Coefficients }\end{array}$} & \multirow{2}{*}{$\begin{array}{c}\text { Standardized } \\
\text { Coefficients }\end{array}$} & \multirow[b]{2}{*}{$\mathrm{T}$} & \multirow[b]{2}{*}{ Sig. } & \multicolumn{2}{|c|}{$\begin{array}{l}\text { Collinearity } \\
\text { Statistics }\end{array}$} \\
\hline & B & Std. Error & & & & Tolerance & VIF \\
\hline 1 (Constant) & 6,165 & 5,559 & & 1,109 & 272 & & \\
\hline TotalX1 & ,435 &, 158 & ,406 & 3,857 & 000 & 718 & 1,392 \\
\hline TotalX2 &, 709 &, 144 &, 536 & 4,912 &, 000 & ,931 & 1,074 \\
\hline TotalX3 & ,420 & ,158 & ,320 & 2,661 & ,010 & ,765 & 1,308 \\
\hline
\end{tabular}

\section{Regresi Linier Berganda}

Penelitian ini bertujuan melihat pengaruh hubungan antara variabel-variabel independen terhadap variabel dependen dengan menggunakan analisis regresi linear berganda. Statistik untuk menguji hipotesis dalam penelitian ini menggunakan metode regresi linier berganda.

Tabel 1. Uji Analisis Regresi Linier Berganda

a. Dependent Variable: TotalY

Sumber: Hasil Pengolahan SPSS Versi 22.0, (2021)

Berdasarkan perhitungan yang dilakukan menggunakan SPSS 22.0 di atas akan didapat persamaan regresi berganda model regresi sebagai berikut:

$$
\mathrm{Y}=6,165+0,435 \mathrm{X} 1+0,709 \mathrm{X} 2+0,420 \mathrm{X} 3
$$

Berdasarkan persamaan regresi tersebut dianalisis pengaruh komunikasi, motivasi dan lingkungan kerja terhadap kinerja yaitu:

1. 6,165 menunjukkan bahwa apabila variabel komunikasi, motivasi dan lingkungan kerja (0) maka nilai kinerja sebesar 6,165.

2. 0,435 menunjukkan bahwa apabila variabel komunikasi ditingkatkan satu satuan point maka nilai kinerja akan bertambah bertambah 0,435 . 
3. 0,709 menunjukkan bahwa apabila variabel motivasi ditingkatkan satu satuan point maka nilai kinerja akan bertambah bertambah 0,483 .

4. 0,420 menunjukkan bahwa apabila variabel lingkungan kerja ditingkatkan satu satuan point maka nilai kinerja akan bertambah bertambah 0,483.

\section{Uji Hipotesis}

\section{Uji t}

Uji t dilakukan untuk mengetahui pengaruh masing-masing variabel independen yang terdiri atas lingkungan kerja dan pengembangan karir terhadap kinerja . Adapun langkah-langkah yang harus dilakukan dalam uji ini adalah sebagai berikut

1). Merumuskan hipotesis

H0 :tidak ada pengaruh komunikasi, motivasi dan lingkungan kerja terhadap kinerja.

$\mathrm{H} 1$ : ada pengaruh komunikasi, motivasi dan lingkungan kerja terhadap kinerja

Jika $t_{\text {sig }}>0.05=$ Ho diterima $\mathrm{H}_{1}$ ditolak.

Jika $\mathrm{t}_{\text {sig }} \leq 0.05=$, Ho ditolak $\mathrm{H}_{1}$ diterima

Tabel 2. Uji t



Sumber: Hasil Pengolahan SPSS Versi 22.0, (2021)

1. Pengaruh komunikasi terhadap kinerja

Pengujian signifikan dengan kriteria pengambilan keputusan:

Ha diterima dan $\mathrm{HO}$ ditolak, apabila thitung $>\mathrm{t}_{\text {tabel }}$ atau Sig. $\mathrm{t}<\alpha$

Ha ditolak dan H0 diterima, apabila thitung $<t_{\text {tabel }}$ atau Sig. $\mathrm{t}>\alpha$

Dari hasil penelitian ini diperoleh nilai signifikansi komunikasi terhadap Kinerja berdasarkan uji $t$ diperoleh sebesar thitung $>t_{\text {tabel }}(3,857>2,001)$. dengan demikian $\mathrm{H}_{\mathrm{a}}$ diterima. kesimpulannya: Komunikasi berpengaruh positif dan signifikan terhadap Kinerja pada PT. Nutrifood Medan.

2. Pengaruh motivasi terhadap kinerja

Pengujian signifikan dengan kriteria pengambilan keputusan:

Ha diterima dan $\mathrm{HO}$ ditolak, apabila thitung $>t_{\text {tabel }}$ atau Sig. $t<\alpha$

Ha ditolak dan H0 diterima, apabila thitung $<t_{\text {tabel }}$ atau Sig. $t>\alpha$

Dari hasil penelitian ini diperoleh nilai signifikansi motivasi berdasarkan uji t diperoleh sebesar thitung $>t_{\text {tabel }}(4,912>2,001)$. dengan demikian $\mathrm{H}_{\mathrm{a}}$ diterima. kesimpulannya: motivasi berpengaruh positif dan signifikan terhadap kinerja karyawan pada PT. Nutrifood Medan.

3. Pengaruh motivasi terhadap kinerja

Pengujian signifikan dengan kriteria pengambilan keputusan:

Ha diterima dan $\mathrm{HO}$ ditolak, apabila thitung $>\mathrm{t}_{\text {tabel }}$ atau Sig. $\mathrm{t}<\alpha$

Ha ditolak dan H0 diterima, apabila thitung $<t_{\text {tabel }}$ atau Sig. $t>\alpha$

Dari hasil penelitian ini diperoleh nilai signifikansi lingkungan kerja berdasarkan uji t diperoleh sebesar thitung $>t_{\text {tabel }}(2,661>2,001)$. dengan demikian $\mathrm{H}_{1}$ diterima. kesimpulannya: lingkungan kerja berpengaruh positif dan signifikan terhadap kinerja karyawan pada PT. Nutrifood Medan.

\section{Uji F}

Uji F dilakukan untuk melihat pengaruh variabel bebas secara bersama-sama terhadap variabel tidak bebas. Tahapan uji F sebagai berikut:

1). Merumuskan hipotesis

H0 : tidak ada pengaruh komunikasi, motivasi dan lingkungan kerja terhadap kinerja. 
H1 : ada pengaruh komunikasi, motivasi dan lingkungan kerja terhadap kinerja

2). Membandingkan hasil $\mathrm{F}_{\text {sig }}$ dengan $\operatorname{Sig}(0,05)$ dengan kriteria sebagai berikut:

Jika $\mathrm{F}_{\text {sig }}>0.05=$ Ho diterima

Jika $\mathrm{F}_{\text {sig }}<0.05=\mathrm{H}_{1}$ diterima.

Tabel 3. Uji F

\begin{tabular}{|l|l|r|r|r|r|c|}
\hline Model & Sum of Squares & Df & Mean Square & F & Sig. \\
\hline \multirow{4}{*}{1} & Regression & 283,519 & 3 & 94,506 & 11,429 &, $000^{\mathrm{b}}$ \\
\cline { 2 - 7 } & Residual & 463,064 & 76 & 8,269 & & \\
\cline { 2 - 7 } & Total & 746,583 & 79 & & & \\
\hline
\end{tabular}

Berdasarkan hasil uji $\mathrm{F}$ di atas diperoleh nilai $\mathrm{F}_{\text {hitung }}>\mathrm{F}_{\text {tabel }}$ sebesar $(25,636>3,16)($ Sig. $0.000<$ a0.05), dengan demikian $\mathrm{H}_{0}$ ditolak . kesimpulannya: ada pengaruh signifikan pengaruh Komunikasi, motivasi dan lingkungan kerja terhadap Kinerja pada PT. Nutrifood Medan.

\section{Koefisien Determinasi (R-Square)}

(Sugiyono, 2010) Koefisien determinasi (R-Square) digunakan dalam penelitian ini untuk melihat bagaimana variasi nilai variabel terikat dipengaruhi oleh variasi nilai variabel bebas yaitu dengan mengkuadratkan koefisien yang ditemukan. Dalam penggunaanya, koefisien determinasi ini dinyatakan dalam persentase (\%) dengan rumussebagai berikut:

Tabel 4. Uji Determinasi

\begin{tabular}{|l|r|r|r|r|}
\hline & & & & \\
Model & $\mathrm{R}$ & R Square & $\begin{array}{c}\text { Adjusted R } \\
\text { Square }\end{array}$ & $\begin{array}{c}\text { Std. Error of the } \\
\text { Estimate }\end{array}$ \\
\hline 1 &, $616^{\mathrm{a}}$ &, 380 &, 347 & 2,87559 \\
\hline
\end{tabular}

Sumber: Hasil Pengolahan SPSS Versi 22.0, (2021)

Dari hasil Nilai Adjust R-Square sebesar 0.347 atau 34,7\% menunjukkan kontribusi komunikasi, motivasi dan lingkungan kerja terhadap Kinerja sisanya 65,3\% dipengaruhi oleh faktor lain atau variable lain yang tidak diteliti.

\section{Pengaruh Komunikasi Terhadap Kinerja}

Hasil penelitian menunjukkan bahwa komunikasi berpengaruh terhadap kinerja. Hal ini dapat dilihat dari analisis regresi linier berganda melalui uji t yang bertanda positif dengan uji tiperoleh sebesar thitung 3,857 dengan signifikan 0,000. Berdasarkan hasil tersebut, maka dapat disimpulkan bahwa Hipotesis 1 (satu) dalam penelitian ini teruji dan dapat diterima. Arah positif menunjukkan bahwa setiap ada peningkatan komunikasi yang dilakukan oleh karyawan PT.Nutrifood Medan, akan menyebabkan meningkatnya kinerja PT.Nutrifood Medan secara bersamaan sebesar 0,435 satuan. Dengan kata lain ketika komunikasi di PT.Nutrifood Medan yang terdiri dari pemahaman ,pengaruh dan sikap, tindakan ,hubungan, waktu, kualitas, dan kuantitas meningkat maka kinerja karyawan PT.Nutrifood Medan akan meningkat pula, menunjukkan bahwa komunikasi berpengaruh positif dan signifikan terhadap kinerja.

Hasil penelitian ini sesuai dengan penelitian terdahulu untuk mengetahui apakah komunikasi berpengaruh positif dan signifikan terhadap kinerja pegawai pada PT.Nutrifood Medan. Hal ini sejalan dengan hasil penelitian menyimpulkan bahwa komunikasi berpengaruh signifikan terhadap kinerja karyawan (Fachrezi \& Khair, 2020; Julita \& Arianty, 2019; Kamal, 2015; Wandi et al., 2019).

\section{Pengaruh Motivasi Terhadap Kinerja}

Hasil penelitian menunjukkan bahwa motivasi berpengaruh terhadap kinerja. Hal ini dapat dilihat dari analisis regresi linier berganda melalui uji t yang bertanda positif dengan uji $t$ diperoleh 
sebesar thitung 4,912 dengan signifikan 0,000. Berdasarkan hasil tersebut, maka dapat disimpulkan bahwa Hipotesis 2 (dua) dalam penelitian ini teruji dan dapat diterima. Arah positif menunjukkan bahwa setiap ada peningkatan motivasi yang dilakukan oleh PT.Nutrifood Medan, akan menyebabkan meningkatnya kinerja pegawai PT.Nutrifood Medan secara bersamaan sebesar 0,709 satuan. Dengan kata lain ketika motivasi di PT.Nutrifood Medan yang terdiri dari pemahaman, tindakan, kualitas kerja, kuantitas kerja, waktu,dan kerja keras maka motivasi karyawan di PT.Nutrifood Medan akan meningkat pula.

Hasil penelitian ini sesuai dengan penelitian terdahulu untuk mengetahui apakah komunikasi berpengaruh positif dan signifikan terhadap kinerja pegawai pada PT.Nutrifood Medan. Hal ini sejalan dengan hasil penelitian terdahulu yang menyatakan bahwa motivasi kerja berpengaruh secara signifikan dan positif terhadap kinerja karyawan (Jufrizen \& Pulungan, 2017), (Astuti \& Suhendri, 2019), (Jufrizen \& Hadi, 2021), (Sembiring et al., 2021), (Jufrizen, 2017).

\section{Pengaruh Lingkungan kerja Terhadap Kinerja}

Hasil penelitian menunjukkan bahwa lingkungan kerja berpengaruh terhadap kinerja. Hal ini dapat dilihat dari analisis regresi linier berganda melalui uji t yang bertanda positif dengan uji $t$ diperoleh sebesar thitung 2,661 dengan signifikan 0,000. Berdasarkan hasil tersebut, maka dapat disimpulkan bahwa Hipotesis 3 (tiga) dalam penelitian ini teruji dan dapat diterima. Arah positif menunjukkan bahwa setiap ada peningkatan lingkungan kerja yang dilakukan oleh PT.Nutrifood Medan, akan menyebabkan meningkatnya kinerja pegawai PT.Nutrifood Medan secara bersamaan sebesar 0,420 satuan. Dengan kata lain ketika lingkungan kerja di PT.Nutrifood Medan yang terdiri dari penerangan, suhu udara, kualitas, kuantitas, waktu, dan keamanan maka komunikasi karyawan PT.Nutrifood Medan akan meningkat pula.

Hasil penelitian ini sesuai dengan penelitian terdahulu untuk mengetahui apakah komunikasi berpengaruh positif dan signifikan terhadap kinerja pegawai pada PT.Nutrifood Medan. Hal tersebut sejalan dengan hasil penelitian terdahulu yang hasil penelitiannya menyatakan bahwa lingkungan kerja memiliki pengaruh yang positif dan signifikan terhadap kinerja karyawan (Elizar \& Tanjung, 2018; Fachrezi \& Khair, 2020; Farisi \& Fani, 2019; Jufrizen \& Rahmadhani, 2020).

\section{Pengaruh Komunikasi, Motivasi, Lingkungan kerja Terhadap Kinerja}

Hasil penelitian menunjukkan bahwa komunikasi, motivasi dan lingkungan kerja berpengaruh terhadap kinerja. Hal ini terlihat dari analisis regresi linier berganda melalui uji $\mathrm{F}$ yang bertanda positif dengan nilai $F_{\text {hitung }}$ sebesar 11,429 dengan sig. 0,000. Berdasarkan hasil tersebut, maka dapat disimpulkan bahwa 4 (empat) Hipotesis dalam penelitian ini teruji dan diterima. Arah positif menunjukkan bahwa ada komunikasi, motivasi dan lingkungan kerja, akan menyebabkan meningkatnya kinerja pegawai PT.Nutrifood Medan secara bersamaan. Hal ini sejalan dengan hasil penelitian terdahulu yang menyatakan bahwa komunikasi kerja, motivasi kerja dan lingkungan kerja berpengaruh positif terhadap kinerja karyawan (Andayani \& Tirtayasa, 2019; Bahagia, Pratami Putri, \& Rizdwansyah, 2018; Lesmana \& Gunawan, 2007; Marliani, 2016).

Penelitian ini bertujuan melihat pengaruh hubungan antara variabel-variabel independen terhadap variabel dependen dengan menggunakan analisis regresi linear berganda. Statistik untuk menguji hipotesis dalam penelitian ini menggunakan metode regresi linier berganda.

Tabel 1. Uji Analisis Regresi Linier Berganda

\begin{tabular}{|c|c|c|c|c|c|c|c|}
\hline \multirow[b]{2}{*}{ Model } & \multicolumn{2}{|c|}{$\begin{array}{c}\text { Unstandardized } \\
\text { Coefficients }\end{array}$} & \multirow{2}{*}{$\begin{array}{c}\text { Standardized } \\
\text { Coefficients }\end{array}$} & \multirow[b]{2}{*}{$\mathrm{T}$} & \multirow[b]{2}{*}{ Sig. } & \multicolumn{2}{|c|}{$\begin{array}{l}\text { Collinearity } \\
\text { Statistics }\end{array}$} \\
\hline & $\mathrm{B}$ & Std. Error & & & & Tolerance & VIF \\
\hline $1 \quad$ (Constant) & 6,165 & 5,559 & & 1,109 & ,272 & & \\
\hline TotalX1 &, 435 &, 158 & ,406 & 3,857 & ,000 & ,718 & 1,392 \\
\hline TotalX2 & ,709 &, 144 &, 536 & 4,912 & , 000 & ,931 & 1,074 \\
\hline TotalX3 & , 420 &, 158 & ,320 & 2,661 & , &, 765 & 1,308 \\
\hline
\end{tabular}

Sumber: Hasil Pengolahan SPSS Versi 22.0, (2021) 
Berdasarkan perhitungan yang dilakukan menggunakan SPSS 22.0 di atas akan didapat persamaan regresi berganda model regresi sebagai berikut:

$$
\mathrm{Y}=6,165+0,435 \mathrm{X} 1+0,709 \mathrm{X} 2+0,420 \mathrm{X} 3
$$

Berdasarkan persamaan regresi tersebut dianalisis pengaruh komunikasi, motivasi dan lingkungan kerja terhadap kinerja yaitu:

5. 6,165 menunjukkan bahwa apabila variabel komunikasi, motivasi dan lingkungan kerja (0) maka nilai kinerja sebesar 6,165.

6. 0,435 menunjukkan bahwa apabila variabel komunikasi ditingkatkan satu satuan point maka nilai kinerja akan bertambah bertambah 0,435 .

7. 0,709 menunjukkan bahwa apabila variabel motivasi ditingkatkan satu satuan point maka nilai kinerja akan bertambah bertambah 0,483 .

8. 0,420 menunjukkan bahwa apabila variabel lingkungan kerja ditingkatkan satu satuan point maka nilai kinerja akan bertambah bertambah 0,483 .

\section{Uji Hipotesis}

\section{Uji t}

Uji t dilakukan untuk mengetahui pengaruh masing-masing variabel independen yang terdiri atas lingkungan kerja dan pengembangan karir terhadap kinerja . Adapun langkah-langkah yang harus dilakukan dalam uji ini adalah sebagai berikut

1). Merumuskan hipotesis

H0 :tidak ada pengaruh komunikasi, motivasi dan lingkungan kerja terhadap kinerja.

$\mathrm{H} 1$ : ada pengaruh komunikasi, motivasi dan lingkungan kerja terhadap kinerja

Jika $\mathrm{t}_{\text {sig }}>0.05=$ Ho diterima $\mathrm{H}_{1}$ ditolak.

Jika $\mathrm{t}_{\text {sig }} \leq 0.05=$, Ho ditolak $\mathrm{H}_{1}$ diterima

Tabel 2. Uji t

\begin{tabular}{|c|c|c|c|c|c|c|c|c|}
\hline \multirow{2}{*}{\multicolumn{2}{|c|}{ Model }} & \multicolumn{2}{|c|}{$\begin{array}{c}\text { Unstandardized } \\
\text { Coefficients }\end{array}$} & \multirow{2}{*}{$\begin{array}{c}\text { Standardized } \\
\text { Coefficients }\end{array}$} & \multirow[b]{2}{*}{$\mathrm{t}$} & \multirow[b]{2}{*}{ Sig. } & \multicolumn{2}{|c|}{$\begin{array}{l}\text { Collinearity } \\
\text { Statistics }\end{array}$} \\
\hline & & B & Std. Error & & & & Tolerance & VIF \\
\hline 1 & (Constant) & 6,165 & 5,559 & & 1,109 & .272 & & \\
\hline & TotalX1 & 435 &, 158 & 406 & 3,857 & .000 & .718 & 1,392 \\
\hline & TotalX2 & ,709 &, 144 &, 536 & 4,912 &, 000 & ,931 & 1,074 \\
\hline & TotalX3 &, 420 &, 158 & ,320 & 2,661 & ,010 &, 765 & 1,308 \\
\hline
\end{tabular}

Sumber: Hasil Pengolahan SPSS Versi 22.0, (2021)

4. Pengaruh komunikasi terhadap kinerja

Pengujian signifikan dengan kriteria pengambilan keputusan:

Ha diterima dan $\mathrm{HO}$ ditolak, apabila thitung $>\mathrm{t}_{\text {tabel }}$ atau Sig. $\mathrm{t}<\alpha$

Ha ditolak dan $\mathrm{H} 0$ diterima, apabila $t_{\text {hitung }}<t_{\text {tabel }}$ atau Sig. $t>\alpha$

Dari hasil penelitian ini diperoleh nilai signifikansi komunikasi terhadap Kinerja berdasarkan uji t diperoleh sebesar thitung $>t_{\text {tabel }}(3,857>2,001)$. dengan demikian $\mathrm{H}_{\mathrm{a}}$ diterima. kesimpulannya: Komunikasi berpengaruh positif dan signifikan terhadap Kinerja pada PT. Nutrifood Medan.

5. Pengaruh motivasi terhadap kinerja

Pengujian signifikan dengan kriteria pengambilan keputusan:

Ha diterima dan $\mathrm{H} 0$ ditolak, apabila $t_{\text {hitung }}>\mathrm{t}_{\text {tabel }}$ atau Sig. $\mathrm{t}<\alpha$

Ha ditolak dan $\mathrm{H} 0$ diterima, apabila thitung $<\mathrm{t}_{\text {tabel }}$ atau Sig. $\mathrm{t}>\alpha$

Dari hasil penelitian ini diperoleh nilai signifikansi motivasi berdasarkan uji t diperoleh sebesar thitung $>$ tabel $(4,912>2,001)$. dengan demikian $\mathrm{H}_{\mathrm{a}}$ diterima. kesimpulannya: motivasi berpengaruh positif dan signifikan terhadap kinerja karyawan pada PT. Nutrifood Medan.

6. Pengaruh motivasi terhadap kinerja 
Pengujian signifikan dengan kriteria pengambilan keputusan:

Ha diterima dan $\mathrm{H} 0$ ditolak, apabila thitung $>t_{\text {tabel }}$ atau Sig. $\mathrm{t}<\alpha$

Ha ditolak dan H0 diterima, apabila thitung $<t_{\text {tabel }}$ atau Sig. $t>\alpha$

Dari hasil penelitian ini diperoleh nilai signifikansi lingkungan kerja berdasarkan uji t diperoleh sebesar thitung $>t_{\text {tabel }}(2,661>2,001)$. dengan demikian $\mathrm{H}_{1}$ diterima. kesimpulannya: lingkungan kerja berpengaruh positif dan signifikan terhadap kinerja karyawan pada PT. Nutrifood Medan.

\section{Uji F}

Uji F dilakukan untuk melihat pengaruh variabel bebas secara bersama-sama terhadap variabel tidak bebas. Tahapan uji F sebagai berikut:

1). Merumuskan hipotesis

H0 : tidak ada pengaruh komunikasi, motivasi dan lingkungan kerja terhadap kinerja.

$\mathrm{H} 1$ : ada pengaruh komunikasi, motivasi dan lingkungan kerja terhadap kinerja

2). Membandingkan hasil $F_{\text {sig }}$ dengan Sig $(0,05)$ dengan kriteria sebagai berikut:

Jika $\mathrm{F}_{\text {sig }}>0.05=$ Ho diterima

Jika $\mathrm{F}_{\text {sig }}<0.05=\mathrm{H}_{1}$ diterima.

Tabel 3. Uji F

\begin{tabular}{|l|l|r|r|r|r|c|}
\hline Model & Sum of Squares & Df & Mean Square & F & \multicolumn{1}{c|}{ Sig. } \\
\hline 1 & Regression & 283,519 & 3 & 94,506 & 11,429 &, $000^{\mathrm{b}}$ \\
\cline { 2 - 7 } & Residual & 463,064 & 76 & 8,269 & & \\
\cline { 2 - 7 } & Total & 746,583 & 79 & & & \\
\hline
\end{tabular}

Berdasarkan hasil uji $\mathrm{F}$ di atas diperoleh nilai $\mathrm{F}_{\text {hitung }}>\mathrm{F}_{\text {tabel }}$ Sebesar $(25,636>3,16)$ (Sig. $0.000<$ $\alpha 0.05$ ), dengan demikian $\mathrm{H}_{0}$ ditolak . kesimpulannya: ada pengaruh signifikan pengaruh Komunikasi, motivasi dan lingkungan kerja terhadap Kinerja pada PT. Nutrifood Medan.

\section{Koefisien Determinasi (R-Square)}

(Sugiyono, 2010) Koefisien determinasi (R-Square) digunakan dalam penelitian ini untuk melihat bagaimana variasi nilai variabel terikat dipengaruhi oleh variasi nilai variabel bebas yaitu dengan mengkuadratkan koefisien yang ditemukan. Dalam penggunaanya, koefisien determinasi ini dinyatakan dalam persentase (\%) dengan rumussebagai berikut:

Tabel 4. Uji Determinasi

\begin{tabular}{|l|c|r|r|r|}
\hline & & & & \\
Model & $\mathrm{R}$ & R Square & $\begin{array}{c}\text { Adjusted R } \\
\text { Square }\end{array}$ & $\begin{array}{c}\text { Std. Error of the } \\
\text { Estimate }\end{array}$ \\
\hline 1 &, $616^{\mathrm{a}}$ &, 380 &, 347 & 2,87559 \\
\hline
\end{tabular}

Sumber: Hasil Pengolahan SPSS Versi 22.0, (2021)

Dari hasil Nilai Adjust $R$-Square sebesar 0.347 atau 34,7\% menunjukkan kontribusi komunikasi, motivasi dan lingkungan kerja terhadap Kinerja sisanya 65,3\% dipengaruhi oleh faktor lain atau variable lain yang tidak diteliti.

\section{Pengaruh Komunikasi Terhadap Kinerja}

Hasil penelitian menunjukkan bahwa komunikasi berpengaruh terhadap kinerja. Hal ini dapat dilihat dari analisis regresi linier berganda melalui uji t yang bertanda positif dengan uji t diperoleh sebesar thitung 3,857 dengan signifikan 0,000. Berdasarkan hasil tersebut, maka dapat disimpulkan bahwa Hipotesis 1 (satu) dalam penelitian ini teruji dan dapat diterima. Arah positif menunjukkan bahwa setiap ada peningkatan komunikasi yang dilakukan oleh karyawan PT.Nutrifood Medan, akan menyebabkan meningkatnya kinerja PT.Nutrifood Medan secara bersamaan sebesar 0,435 satuan. Dengan kata lain ketika komunikasi di PT.Nutrifood Medan yang terdiri dari pemahaman 
,pengaruh dan sikap, tindakan ,hubungan, waktu, kualitas, dan kuantitas meningkat maka kinerja karyawan PT.Nutrifood Medan akan meningkat pula, menunjukkan bahwa komunikasi berpengaruh positif dan signifikan terhadap kinerja.

Hasil penelitian ini sesuai dengan penelitian terdahulu untuk mengetahui apakah komunikasi berpengaruh positif dan signifikan terhadap kinerja pegawai pada PT.Nutrifood Medan. Hal ini sejalan dengan hasil penelitian menyimpulkan bahwa komunikasi berpengaruh signifikan terhadap kinerja karyawan (Fachrezi \& Khair, 2020; Julita \& Arianty, 2019; Kamal, 2015; Wandi et al., 2019).

\section{Pengaruh Motivasi Terhadap Kinerja}

Hasil penelitian menunjukkan bahwa motivasi berpengaruh terhadap kinerja. Hal ini dapat dilihat dari analisis regresi linier berganda melalui uji t yang bertanda positif dengan uji $t$ diperoleh sebesar thitung 4,912 dengan signifikan 0,000. Berdasarkan hasil tersebut, maka dapat disimpulkan bahwa Hipotesis 2 (dua) dalam penelitian ini teruji dan dapat diterima. Arah positif menunjukkan bahwa setiap ada peningkatan motivasi yang dilakukan oleh PT.Nutrifood Medan, akan menyebabkan meningkatnya kinerja pegawai PT.Nutrifood Medan secara bersamaan sebesar 0,709 satuan. Dengan kata lain ketika motivasi di PT.Nutrifood Medan yang terdiri dari pemahaman, tindakan, kualitas kerja, kuantitas kerja, waktu,dan kerja keras maka motivasi karyawan di PT.Nutrifood Medan akan meningkat pula.

Hasil penelitian ini sesuai dengan penelitian terdahulu untuk mengetahui apakah komunikasi berpengaruh positif dan signifikan terhadap kinerja pegawai pada PT.Nutrifood Medan. Hal ini sejalan dengan hasil penelitian terdahulu yang menyatakan bahwa motivasi kerja berpengaruh secara signifikan dan positif terhadap kinerja karyawan (Jufrizen \& Pulungan, 2017), (Astuti \& Suhendri, 2019), (Jufrizen \& Hadi, 2021), (Sembiring et al., 2021), (Jufrizen, 2017).

\section{Pengaruh Lingkungan kerja Terhadap Kinerja}

Hasil penelitian menunjukkan bahwa lingkungan kerja berpengaruh terhadap kinerja. Hal ini dapat dilihat dari analisis regresi linier berganda melalui uji t yang bertanda positif dengan uji $t$ diperoleh sebesar thitung 2,661 dengan signifikan 0,000. Berdasarkan hasil tersebut, maka dapat disimpulkan bahwa Hipotesis 3 (tiga) dalam penelitian ini teruji dan dapat diterima. Arah positif menunjukkan bahwa setiap ada peningkatan lingkungan kerja yang dilakukan oleh PT.Nutrifood Medan, akan menyebabkan meningkatnya kinerja pegawai PT.Nutrifood Medan secara bersamaan sebesar 0,420 satuan. Dengan kata lain ketika lingkungan kerja di PT.Nutrifood Medan yang terdiri dari penerangan, suhu udara, kualitas, kuantitas, waktu, dan keamanan maka komunikasi karyawan PT.Nutrifood Medan akan meningkat pula.

Hasil penelitian ini sesuai dengan penelitian terdahulu untuk mengetahui apakah komunikasi berpengaruh positif dan signifikan terhadap kinerja pegawai pada PT.Nutrifood Medan. Hal tersebut sejalan dengan hasil penelitian terdahulu yang hasil penelitiannya menyatakan bahwa lingkungan kerja memiliki pengaruh yang positif dan signifikan terhadap kinerja karyawan (Elizar \& Tanjung, 2018; Fachrezi \& Khair, 2020; Farisi \& Fani, 2019; Jufrizen \& Rahmadhani, 2020).

\section{Pengaruh Komunikasi, Motivasi, Lingkungan kerja Terhadap Kinerja}

Hasil penelitian menunjukkan bahwa komunikasi, motivasi dan lingkungan kerja berpengaruh terhadap kinerja. Hal ini terlihat dari analisis regresi linier berganda melalui uji $\mathrm{F}$ yang bertanda

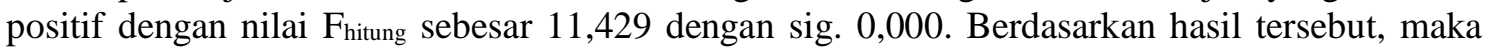
dapat disimpulkan bahwa 4 (empat) Hipotesis dalam penelitian ini teruji dan diterima. Arah positif menunjukkan bahwa ada komunikasi, motivasi dan lingkungan kerja, akan menyebabkan meningkatnya kinerja pegawai PT.Nutrifood Medan secara bersamaan. Hal ini sejalan dengan hasil penelitian terdahulu yang menyatakan bahwa komunikasi kerja, motivasi kerja dan lingkungan kerja berpengaruh positif terhadap kinerja karyawan (Andayani \& Tirtayasa, 2019; Bahagia, Pratami Putri, \& Rizdwansyah, 2018; Lesmana \& Gunawan, 2007; Marliani, 2016). 


\section{KESIMPULAN}

Berdasarkan pemaparan diatas maka dapat di ambil kesimpulan bahwa : Komunikasi berpengaruh positif dan signifikan terhadap kinerja PT.Nutrifood Medan Motivasi berpengaruh positif dan signifikan terhadap kinerja karyawan PT.Nutrifood Medan. Lingkungan kerja berpengaruh positif dan signifikan terhadap kinerja karyawan PT.Nutrifood Medan. Secara simultan Komunikasi, penempatan pegawai dan lingkungan kerja berpengaruh positif dan signifikan terhadap kinerja karyawan PT.Nutrifood Medan.

Adapun saran yang diberikan pada penelitian ini perusahaan sebaiknya memperkerjakan karyawan sesuai dengan kemampuannya dan juga selalu memberikan feedback atas setiap pekerjaan yang telah dikerjakan pegawai, dan selanjutnya disarankan juga kepada perusahaan untuk memperhatikan beban kerja yang diberikan untuk pegawai sesuai dengan porsinya dengan solusi pimpinan harus memberikan perhatian dan tugas pekerjaan yang merata kepada karyawannya. Perusahaan sebaiknya memberikan pembinaan kepada pegawai agar selalu berkerja dan bersikap positif dalam mengerjakan pekerjaannya dan atasan wajib memberikan dorongan dan apresiasi kepada pegawai agar meningkatkan kualitas, dan selanjutnya disarankan juga kepada perusahaan untuk memperhatikan karyawan yang lebih mendahulukan pekerjaan pribadinya dibandingkan pekerjaan kantor dengan solusi atasan harus lebih memotivasi pegawainya sehingga pegawai merasa diperhatikan sehingga lebih professional dalam melakukan pekerjaannya.

\section{DAFTAR PUSTAKA}

Andayani, I., \& Tirtayasa, S. (2019). Pengaruh Kepemimpinan, Budaya Organisasi, dan Motivasi Terhadap Kinerja Pegawai. Maneggio: Jurnal Ilmiah Magister Manajemen, 2(1), 45-54. https://doi.org/http://doi.org/10.30596/maneggio.v2i1.3367

Ardiansyah, D. O. (2016). Pengaruh Komunikasi Terhadap Kinerja Karyawan Dengan Dimediasi Oleh Kepuasan Kerja (Studi Pada Bagian Produksi Pabrik Kertas PT. Setia Kawan Makmur Sejahtera Tulungagung). Jurnal Bisnis Dan Manajemen, 3(1), 16-30.

Astuti, R., \& Suhendri, S. (2019). Pengaruh Kompensasi Dan Motivasi Terhadap Kinerja Karyawan Pada PT. Tunas Jaya Utama. Jurnal Manajemen Bisnis Eka Prasetya (MBEP), 5(2), 1-10.

Bahagia, R., Pratami Putri, L., \& Rizdwansyah, T. (2018). Pengaruh Kepemimpinan Dan Lingkungan Kerja Terhadap Kinerja Karyawan Pada PT Pegadaian (Persero) Kanwil I Medan. Prosiding Seminar Nasional Vokasi Indonesia, 1, 100-105.

Elizar, E., \& Tanjung, H. (2018). Pengaruh Pelatihan, Kompetensi, Lingkungan Kerja Terhadap Kinerja Pegawai. Maneggio: Jurnal Ilmiah Magister Manajemen, 1(1), 46-58. https://doi.org/https://doi.org/10.30596/maneggio.vlil.2239

Fachrezi, H., \& Khair, H. (2020). Pengaruh Komunikasi, Motivasi dan Lingkungan Kerja Terhadap Kinerja Karyawan Pada PT. Angkasa Pura II (Persero) Kantor Cabang Kualanamu. Maneggio: Jurnal Ilmiah Magister Manajemen, 3(1), 107-119.

Farisi, S., \& Fani, W. M. (2019). Influence of Work Environment and Work Dicipline on Employee performance. International Conference on Global Education VII, 69-81.

Farisi, S., Irnawati, J., \& Fahmi, M. (2020). Pengaruh Motivasi dan Disiplin Kerja Terhadap Kinerja Karyawan. Jurnal Humaniora : Jurnal Ilmu Sosial, Ekonomi Dan Hukum, 4(1), 1533. https://doi.org/10.30601/humaniora.v4i1.420

Gultom, D. K. (2014). Pengaruh Budaya Organisasi Perusahaan Dan Motivasi Terhadap Kinerja Karyawan pada PT. Perusahaan Gas Negara (Persero) Tbk Medan. Jurnal Ilmiah Manajemen Dan Bisnis, 14(2), 176-184. https://doi.org/10.30596/jimb.v14i2.194

Hidayat, T., Tanjung, H., \& Juliandi, A. (2020). Motivasi Kerja, Budaya Organisasi Dan Kompetensi Terhadap Kinerja Guru Pada SMK Muhammadyah 3 Aek Kanopan. Jurnal Manajemen Bisnis, 17(2), 189-206. 
Jufrizen, J. (2017). Pengaruh kemampuan dan motivasi terhadap kinerja perawat Studi pada Rumah Sakit Umum Madani Medan. Jurnal Riset Sains Manajemen, 1(1), 27-34. https://doi.org/10.5281/zenodo.1036809

Jufrizen, J., \& Hadi, F. P. (2021). Pengaruh Fasilitas Kerja dan Disiplin Kerja Terhadap Kinerja Karyawan Melalui Motivasi Kerja. Jurnal Sains Manajemen, 7(1), 35-54. https://doi.org/10.30656/sm.v7i1.2277

Jufrizen, J., \& Pulungan, D. R. (2017). Implementation of Incentive and Career Development of Performance with Motivation as an Intervening Variable. Proceedings of AICS-Social Sciences, 441-446.

Jufrizen, J., \& Rahmadhani, K. N. (2020). Pengaruh Budaya Organisasi Terhadap Kinerja Pegawai Dengan Lingkungan Kerja Sebagai Variabel Moderasi. Jurnal Riset Manajemen Dan Bisnis Dewantara, 3(1), 66-79. https://doi.org/10.26533/jmd.v3i1.561

Julita, J., \& Arianty, N. (2019). Pengaruh Komunikasi Dan Lingkungan Kerja Terhadap Kinerja Karyawan Pada Pt. Jasa Marga (Persero) Tbkcabang Belmera Medan. Ekonomi Dan Bisnis Umsu, 195-205.

Kamal, M. B. (2015). Pengaruh Kepemimpinan Dan Pengawasan Terhadap Disiplin Kerja Karyawan Pada PT. Perkebunan Nusantara III (Persero). Jurnal Ilmiah Manajemen Dan Bisnis, 15(01), 61-70.

Kusumastuti, I., Kurniawati, N. I., Satria, D. L., \& Wicaksono, D. (2019). Analisis Pengaruh Lingkungan Kerja Terhadap Kinerja Karyawan Dimediasi Oleh Kepuasan Kerja Karyawan Pada Sp Alumunium Di Yogyakarta. Jurnal REKOMEN (Riset Ekonomi Manajemen), 3(1), 43-53.

Lesmana, S., \& Gunawan, A. (2007). Pengaruh Ketidakpastian Lingkungan Yang Dipersepsikan Dan Strategi Kompetitif Terhadap Hubungan Sistem Kontrol Akuntansi Dengan Kinerja Perusahaan Perbankan Di Kota Medan. Jurnal Riset Akuntansi Dan Bisnis, 7(2), 91-116.

Marjaya, I., \& Pasaribu, F. (2019). Pengaruh Kepemimpinan, Motivasi, Dan Pelatihan Terhadap Kinerja Pegawai. Maneggio: Jurnal Ilmiah Magister Manajemen, 2(1), 129-147. https://doi.org/10.30596/maneggio.v2i1.3650

Marliani, S. (2016). Motivasi Kerja dan Kepuasan Kerja Terhadap Kinerja Karyawan (Studi pada Karyawan PT Bank Negara Indonesia (Persero) Tbk. Cabang Karawang). Jurnal Buana Akuntansi, 1(1), 47-75.

Prayogi, M. A., \& Nursidin, M. (2018). Pengaruh Pelatihan dan Motivasi Kerja Terhadap Kinerja Karyawan. Prosiding Seminar Nasional Multidisiplin Ilmu Universitas Asahan 2018, 216222.

Rivai, A. (2021). Pengaruh Pengawasan, Disiplin dan Motivasi Terhadap Kinerja Guru. Maneggio: Jurnal Ilmiah Magister Manajemen, 4(1), 11-22. https://doi.org/10.30596/maneggio.v4i1.6715

Sembiring, M., Jufrizen, J., \& Tanjung, H. (2021). Efek Mediasi Kepuasan Kerja pada Pengaruh Motivasi Dan Kemampuan Kerja Terhadap Kinerja Pegawai. Maneggio: Junal Ilmiah Magister Manajemen, 4(1), 130-143. https://doi.org/10.30596/maneggio.v4i1.6775

Sugiyono. (2010). Metode Penelitian Pendidikan Pendekatan Kuantitatif, kualitatif, dan R\&D. Bandung: Alfabeta.

Sugiyono. (2018). Metode Penelitian Kuantitatif, Kualitatif, dan R\&D. Bandung: CV. Alfabeta.

Wandi, D., Adha, S., \& Asriyah, I. (2019). Pengaruh Komunikasi Terhadap Kinerja Pegawai Pada Badan Penanggulangan Bencana Daerah (BPBD) Provinsi Banten. Jurnal Ekonomi Vokasi, 2(2), 18-30, ISSN:1098-6596. 